\title{
AKIBAT HUKUM SAHAM YANG DIKELUARKAN PERSEORAN TANPA TERLEBIH DAHULU DITAWARKAN KEPADA PEMEGANG SAHAM
}

\author{
Ghansam Anand \\ Pengamat Hukum, gansam_anand@yahoo.com
}

\begin{abstract}
The principle offreedom of contract was absolutely owned by anyone in making engagement therefore there should be no intervention of the king or state. Exposure theory in this paper aims that every person to own the freedom to enter into an engagement. This freedom also lies not only in his attitude to enter into an engagement but also about the object that is set by the engagement that they make. State, in this case is the government, should not intervene in the engagement that they make.
\end{abstract}

Keyword: Agreement, Company, Stock.

\begin{abstract}
Abstrak
Prinsip kebebasan berkontrak itu mutlak dimiliki oleh setiap orang dalam membuat perikatan oleh karenanya tidak boleh ada intervensi dari raja atau negara. Paparan teori pada tulisan ini bertujuan untuk menenjukan bahwa setiap orang memeliki kebebasan untuk masuk ke dalam suatu perikatan. Kebebasan ini juga terletak tidak hanya pada sikapnya untuk memasuki suatu perikatan tetapi juga mengenai objek yang diatur oleh perikatan yang mereka buat. Negara, dalam hal ini pemerintah, tidak boleh intervensi ke dalam perikatan yang mereka buat.
\end{abstract}

Keywords: Agreement, Perseroan, Shares (Stock)

\section{Pendahuluan}

Undang-undang hanya mengatur orang-orang tertentu yang tidak cakap untuk membuat perjanjian, pengaturan mengenai hal ini dapat dilihat dalam Pasal 1330 BW. Dari ketentuan ini dapat disimpulkan bahwa setiap orang bebas untuk memilih pihak yang ia inginkan untuk membuat perjanjian, asalkan pihak tersebut bukan pihak yang tidak cakap. Bahkan lebih lanjut dalam Pasal 1331 BW ditentukan bahwa apabila seseorang membuat perjanjian dengan pihak yang dianggap tidak cakap menurut pasal 1330 BW tersebut, maka perjanjian itu tetap sah selama tidak dituntut pembatalannya oleh pihak yang tidak cakap (voidable). Larangan kepada seseorang untuk membuat perjanjian dalam bentuk tertentu yang dikehendakinya juga tidak diatur dalam BW Indonesia maupun ketentuan perundangundangan lainnya.

Ketentuan yang ada adalah bahwa untuk perjanjian tertentu harus dibuat dalam bentuk tertentu misalnya perjanjian kuasa memasang Hak Tanggungan harus dibuat dengan akta Notaris atau perjanjian jual beli tanah harus dibuat dengan Pejabat Pembuat Akta Tanah (PPAT). Dengan demikian dapat disimpulkan bahwa 
sepanjang ketentuan perundang-undangan tidak menentukan bahwa suatu perjanjian harus dibuat dalam bentuk tertentu, maka para pihak bebas untuk memilih bentuk perjanjian yang dikehendaki, yaitu apakah perjanjian akan dibuat secara lisan atau tertulis atau perjanjian dibuat dengan akta di bawah tangan atau akta otentik. Pasal 1320 ayat (1) BW menentukan bahwa perjanjian atau kontrak tidak sah apabila dibuat tanpa adanya konsensus atau sepakat dari para pihak yang membuatnya. Ketentuan tersebut mengandung pengertian bahwa kebebasan suatu pihak untuk menentukan isi perjanjian dibatasi oleh sepakat pihak lainnya. Dalam Pasal 1320 ayat (2) BW dapat pula disimpulkan bahwa kebebasan orang untuk membuat perjanjian dibatasi oleh kecakapannya untuk membuat perjanjian. Bagi seseorang yang menurut ketentuan undang-undang tidak cakap untuk membuat perjanjian sama sekali tidak mempunyai kebebasan untuk membuat perjanjian.

Pasal 1320 ayat (3) BW menentukan bahwa obyek perjanjian haruslah dapat ditentukan. Prestasi itu harus tertentu atau sekurang-kurangnya dapat ditentukan, apa yang diperjanjikan harus cukup jelas ditentukan jenisnya, jumlahnya boleh tidak disebutkan asal dapat dihitung atau ditetapkan. Lebih lanjut dalam Pasal 1332 BW menyebutkan bahwa hanya barangbarang yang dapat diperdagangkan saja yang dapat menjadi pokok suatu perjanjian. Syarat bahwa prestasi harus tertentu atau dapat ditentukan gunanya adalah untuk menetapkan hak dan kewajiban kedua belah pihak jika timbul perselisihan dalam pelaksanaan perjanjian. Apabila prestasi samar (kabur) atau dirasakan kurang jelas yang menyebabkan perjanjian itu tidak dapat dilaksanakan, maka obyek perjanjian dianggap tidak ada (null) dan akibat hukumnya perjanjian tersebut batal demi hukum. Pasal 1320 ayat (4) jo. Pasal 1337 BW menentukan bahwa para pihak tidak bebas untuk membuat perjanjian yang menyangkut kausa yang dilarang oleh undang-undang. Kausa atau sebab yang diperbolehkan itu apabila tidak dilarang oleh undang-undang dan tidak bertentangan dengan ketertiban umum dan kesusilaan. Akibat hukum atas perjanjian yang berisi sebab yang tidak diperbolehkan adalah bahwa perjanjian tersebut batal demi hukum.

Pembatasan terhadap prinsip kebebasan berkontrak juga dapat disimpulkan melalui Pasal 1338 ayat (3) BW yang menyatakan bahwa suatu perjanjian hanya dilaksanakan dengan itikad baik. Oleh karena itu para pihak tidak dapat menentukan sekehendak hatinya klausul-klausul yang terdapat dalam perjanjiian tetapi harus didasarkan dan dilaksanakan dengan itikad baik, perjanjian yang didasarkan pada itikad buruk misalnya penipuan. Akibat hukum atas perjanjian tersebut adalah dapat dibatalkan ${ }^{1}$. Sehubungan dengan pembatasan terhadap prinsip kebebasan berkontrak, Asikin Kusuma Atmadja menyatakan bahwa Hakim berwenang untuk memasuki/meneliti isi suatu kontrak apabila diperlukan, karena isi

1 Rosa Agustina T. Pangaribuan, Prinsip Kebebasan Berkontrak dan Batas-Batasnya dalam Hukum Perjanjian, http://www.theceli.com/dokumen/jurnal/rosa/r001. $\underline{\text { shtml }}$ 
dan pelaksanaan suatu kontrak bertentangan dengan nilai-nilai dalam masyarakat ${ }^{2}$.

Berdasarkan uraian diatas, penulis berkesimpulan bahwa kebebasan berkontrak walaupun memang memberi kebebasan yang luas terhadap setiap orang, tetapi terdapat pembatasan. Pembatasan tersebut adalah itikad baik dan peraturan perundangundangan. Dengan demikian sifat memaksa dari undang-undang dapat juga dijadikan batasan kebebasan berkontrak. Jadi a contrario sepanjang isi dariperikatan tersebut mengenai hukum yang bersifat mengatur (aandvullendrecht), maka setiap orang dapat mengecualikannya. Sebaliknya, bila hal yang mau disepakati masuk dalam ketentuan yang bersifat memaksa (dwingendrecht), maka hal tersebut tidak dapat dikecualikan. Oleh karena itu preemptive right yang diatur dalam Pasal 57 ayat (1) Undang-Undang Nomor 40 Tahun 2007 tentang Perseroan Terbatas (selanjutnya disebut UU 40/2007), termasuk ke dalam ketentuan yang bersifat memaksa (dwingendrecht).

\section{Pembahasan}

Perseroan merupakan suatu badan hukum yang mempunyai hak dan kewajiban seperti halnya manusia dan oleh karenanya dapat mengadakan suatu hubungan hukum serta merupakan subjek hukum yang mandiri (Person Standi in Judicio). Sebagai subjek hukum yang mandiri, badan hukum Perseroan dianggap sama dengan manusia biasa yang secara hukum dapat digugat dan menggugat, memberikan kuasa, membuat

\footnotetext{
2 Asikin Kesuma Atmadja, Pembatasan Rentenir sebagai Perwujudan Pemerataan Keadilan, Varia Peradilan, Februari 1987, hal. 17.
}

perjanjian, mengatur kehidupannya sendiri, mempunyai utang piutang serta kekayaan tersendiri layaknya manusia biasa. ${ }^{3}$

Perseroan terbatas juga memberikan kemudahan bagi pemegang saham untuk mengalihkan sebagian ataupun menjual perusahaannya kepada setiap orang dengan menjual seluruh saham yang dimilikinya pada perusahaan tersebut. ${ }^{4}$ Sebagai badan hukum, perseroan memiliki status, kedudukan dan kewenangan yang dapat dipersamakan dengan manusia sehingga disebut artificial legal person, maka ia tidak memiliki kehendak dan tidak dapat bertindak sendiri, Oleh karena itu diperlukan orang-orang yang memiliki kehendak untuk perseroan sesuai tujuan pendiriannya. Orang-orang yang menjalankan, mengurus dan mengawasi perseroan inilah yang disebut organ. Sebagaimana layaknya manusia, perseroan juga memiliki organ, hanya saja organ perseroan hanya tiga, yaitu Rapat Umum Pemegang Sahan (RUPS), Direksi dan Dewan Komisaris. ${ }^{5}$

Direksi adalah organ perseroan pemegang kekuasaan eksekutif di perseroan. Direksi mengendalikan operasi perseroan sehari-hari dalam batas-batas yang ditetapkan oleh UU 40/2007, anggaran dasar dan RUPS serta di bawah pengawasan dewan komisaris. Tugas dan fungsi utama direksi adalah menjalankan roda manajemen perseroan secara menyeluruh. Dengan demikian, setiap anggota direksi haruslah

\footnotetext{
3 http;//en.wikipedia.org/wiki/Corporations, diakses tanggal 10 Desember 2010.

4 Sentosa Sembiring, Hukum Perusahan tentang Perseroan Terbatas, Nuansa Aulia, Bandung, 2006, hal. 1.

5 Ridwan Khairandy, Perseroan sebagai Badan Hukum, Jurnal Hukum Bisnis, Volume 26, 2007, hal 5.
} 
orang yang berwatak baik, berpengalaman, mempunyai kompetensi menduduki jabatan dan melaksanakan setiap kegiatan sematamata untuk kepentingan perseroan. ${ }^{6}$ Ketidaktransparanan direksi dalam hal mengambil keputusan dan cenderung mengambil keuntungan adalah hal yang sering terjadi di dalam suatu perusahaan. Krisis Moneter dan ekonomi yang melanda Indonesia pada tahun 1997 memperlihatkan bukti itu. Perusahaan-perusahaan besar yang dulu begitu kuat, ternyata hancur oleh sistem pengelolaan yang tidak baik, misalnya penggunaan dana untuk investasi jangka panjang sementara dana itu diperlukan perusahaan untuk kegiatan jangka pendek, pengucuran dana yang berlebihan kepada perusahaan yang dalam satu kelompok. ${ }^{7}$

UU 40/2007 mendefinisikan Direksi dalam Pasal 1 angka 5 yakni direksi sebagai organ perseoan yang berwenang dan bertanggungjawab penuh atas pengurusan perseroan untuk kepentingan perseroan, sesuai dengan maksud dan tujuan perseroan serta mewakili perseroan, baik di dalam maupun di luar pengadilan sesuai dengan ketentuan anggaran dasar. Sedangkan untuk menjalankan tugasnya terdapat dalam Pasal 97 ayat (1), yang menyatakan bahwa:

"Direksi bertanggung jawab atas pengurusan Perseroan sebagaimana dimaksud dalam Pasal 92 ayat (1)". ${ }^{8}$

6 Mas Achmad Daniri, Good Corporate Governance Konsep dan Penerapannya dalam Konteks Indonesia, Gloria Printing, Jakarta, 2002, hal 129.

7 M. Irsan Nasaruddin dan Indah Surya, Aspek Hukum Pasar Modal Indonesia, Preneda Media, Jakarta, 2004, hal 244.

8 Pasal 92 ayat (1) "Direksi menjalankan pengurusan Perseroan untuk kepentingan Perseroan dan sesuai dengan maksud dan tujuan Perseroan."
Dalam hal ini perseroan akan tetap terus diwakili oleh Direksi, keberadaan direksi dalam perseroan terbatas ibarat nyawa bagi perseroan, tidak mungkin suatu perseroan tanpa adanya direksi, oleh karena itu, keberadaan direksi dalam perseroan terbatas sangat penting. ${ }^{9}$ Direksi dengan perseroan (korporasi) sebagai badan hukum terdapat hubungan fiduciary ${ }^{10}$ sehingga pihak direksi hanya bertindak seperti seorang trustee atau agen semata yang mempunyai kewajiban mengabdi sepenuhnya dan dengan sebaikbaiknya kepada perseroan. Dalam UU 40/2007 hal ini diatur dalam Pasal 97 ayat (2):

"Pengurusan sebagaimana dimaksud pada ayat (1), wajib dilaksanakan setiap anggota Direksi dengan itikad baik dan penuh tanggung jawab"

Dalam menjalankan tugasnya direksi

\footnotetext{
9 Tri Widiyono, Direksi Perseroan Terbatas, keberadaan, tugas, wewenang, dan tangung jawab, Ghalia, Jakarta, 2008, hal. 40.

10 Teori fiduciary duty adalah suatu kewajiban yang ditetapkan undang-undang bagi seseorang yang memanfaatkan seseorang lain, dimana kepentingan pribadi seseorang yang diurus oleh pribadi lainnya, yang sifatnya hanya hubungan atasan-bawahan sesaat. Orang yang mempunyai kewajiban ini harus melaksanakannya berdasarkan suatu standar dari kewajiban (standard of duty) yang paling tinggi sesuai dengan yang dinyatakan oleh hukum. Sedangkan fiduciary ini adalah seseorang yang memegang peran sebagai suatu wakil (trustee) atau suatu peran yang disamakan dengan sesuatu yang berperan sebagai wakil, dalam hal ini peran tersebut didasarkan kepercayaan dan kerahasiaan (trust and confidence) yang dalam peran ini meliputi, ketelitian (scrupulous), itikad baik (good faith), dan keterusterangan (candor). Fiduciary ini termasuk hubungan seperti, pengurus atau pengelola, pengawas, wakil atau wali, dan pelindung (guardian). termasuk juga di dalamnya seorang lawyer yang mempunyai hubungan fiduciary dengan client-nya. http://bismar. wordpress.com/2009/12/23/pertanggungjawaban direksi diakses tanggal 27 Mei 2010.
} 
harus memperhatikan beberapa prinsipprinsip tanggung jawab direksi dalam menjalankan perseroan yakni duty of skill and care (prinsip kehati-hatian dalam tindakan direksi), duty of loyalty (itikad baik dari direksi semata-mata demi tujuan perseroan) dan no secret profit rule doctrine of corporate opportunity (tidak menggunakan kesempatan pribadi atas kesempatan milik atau peruntukan bagi perseroan) serta memiliki tugas-tugas dan kewajiban yang berdasarkan undang-undang (statutory duty). ${ }^{11}$

Setiap perbuatan pemindahan hak atas saham, orang yang hendak melakukannya memiliki keharusan untuk menawarkan sahamnya terlebih dahulu kepada pemegang saham yang lain. Ketentuan ini mengikat apabila memang diatur dalam anggaran dasar perseroan yang mengeluarkan saham tersebut. ${ }^{12}$ Keharusan untuk menawarkan saham terlebih dahulu ini bila dilihat dari pemegang saham lainnya, maka hal ini disebut sebagai hak memesan saham terlebih dahulu. Hak memesan saham terlebih dahulu dibagi atas 2 (dua), yaitu preemptive right terhadap saham yang masih portepel untuk melakukan peningkatan modal perseroan dan preemptive right terhadap saham yang telah dikeluarkan (tidak terjadi peningkatan modal perseroan). ${ }^{13}$

\section{Preemptive right merupakan}

kepentinganperdata, kepentingan yang bebas

11 Robert J.P, Lebih Jauh tentang Kepailitan, Pusat Studi Hukum Bisnis Fakultas Hukum Pelita Harapan, Jakarta, 1998, hal 5.

12 Pasal 57 UU 40/2007.

13 Lihat Karimsyah Law Firm, "Hak Memesan Efek Terlebih Dahulu (Right Issue)", <hht://www.karimsyah. com/imagescontent/article/20050922170905.pdf >, diakses 1 November 2010. diatur oleh para pihak yang membuatnya. Walaupun demikian ketentuan mengenai preemptive right menentukan keabsahan dari perbuatan pemindahan hak atas saham. Kesimpulannya, maka ketentuan mengenai preemptive right memiliki sifat memaksa (dwingendrecht).

Dalam sistem common law, di beberapa negara bagian Amerika Serikat, setiap pemegang saham harus menjalankan ketentuan mengenai preemptive right walaupun anggaran dasar perseroan yang menegluarkan sahamnya tidak mengatur demikian. ${ }^{14}$ Rasio adanya preeptive right adalah untuk menghindari terjadinya dilusi porsi kepemilikan perseroan oleh pemegang saham dan juga untuk menjaga terdilusinya porsi kontrol perusahaan. ${ }^{15}$ Selain itu preemptive right juga bermaksud untuk memberikan pemilik atau pemegang saham perseroan suatu kesempatan yang pertama dan utama untuk memiliki atau turut memiliki saham yang hendak ditawarkan. ${ }^{16}$ Sedangkan apabila konsep perseroan terbatas dianalogikan dengan konsep persekutuan perdata (maatschap) maka rasio adanya preemptive right adalah untuk mengutamakan manfaat bersama antara sekutu atau dalam hal perseroan terbatas, antara pemegang saham. ${ }^{17}$

Preemptive right tidak diberikan

14 J. David Reitzel, et. Al., Contemporary Business law, Principles an Cases, cetakan ke-4, McGraw-Hill, United States, 1986, hal. 1035.

15 Thomas J. Harron, Business Law, cetakan ke-1, Allyn and Bacon, Massachusets, 1981, hal. 794-795.

16 Agustinus Dawarja, "First Right of Refusal Pengelolaan Sumber Daya Alam Bangsa" <hhtp:www. lexregis.com/?menu=legal_article\&id_la=28>, November 2010.

17 Pasal 1618 BW. 
pengaturan yang jelas dalam UU 40/2007. Hal ini dapat menunjukan bahwa ketentuan lebih lanjut dapat diatur kemudian oleh para pihak dalam anggaran dasar perseroan. Sebagai perbandingan, dalam hukum perusahaan di Swedia, ketentuan mengenai preemptive right dalam peraturan perundangan-undangan secara tegas dinyatakan berlaku dalam perbuatan pengalihan saham melalui akuisisi, jual beli, hibah (tidak termasuk warisan dan hibah wasiat) dan termasuk juga perolehan saham karena prosedur eksekusi atau paulit. ${ }^{18}$ Oleh karena itu, menurut penulis, dalam hukum Indonesia, bila memang para pihak menginginkan ketentuan hak memesan saham terlebih dahulu diatur secara lengkap dan definitif, para pihak (para pemegang saham) melalui Rapat Umum Pemegang Saham (RUPS) harus menetapkan hal-hal yang dikehendaki dalam anggaran dasar.

Dalam UU 40/2007 dikenal dua macam preemptive right, yaitu hak yang diatur dalam Pasal 43 dan Pasal 57-58. Pasal 43 mengatur mengenai keharusan untuk menawarkan terlebih dahulu kepada pemegang saham untuk saham yang dikeluarkan untuk penambahan modal. Sedangkan pasal 5758 mengatur megenai keharusan untuk menawarkan terlebih dahulu penjualan suatu saham yang dimiliki pemegang saham. Berdasarkan Pasal 43 UU 40/2007, preemptive right terhadap saham baru hanya dapat dikecualikan terhadap suatu saham yang dikeluarkan yang ditujukan kepada 18 Roschier Attorneys Ltd, "Preemptive rights, Requirement for Consent and Right of First Refusal in the Article of Association of a Limited Liability Company in Sweden", <http://www.lexuniversal.com/en/ articles/1181>, diakses 1 November 2010. karyawan Perseroan (Employee Stock Option Program), pemegang obligasi atau efek lain yang dapat dikonversikan menjadi saham yang telah disetujui oleh RUPS atau yang dilakukan dalam rangka reorganisasi dan/atau restrukturisasi yang telah disetujui RUPS. Sedangkan berdasarkan Pasal 57 ayat (2) UU 40/2007, preemptive right terhadap saham yang telah dikeluarkan hanya dapat dikesampingkan dalam hal peralihan hak karena hukum, antara lain penggabungan, peleburan atau pemisahan. Jadi dalam kaitannya dengan eksekusi gadai saham, hukum Indonesia tidak dengan jelas mengatur keberlakuannya preemptive right tetap berlaku dalam eksekusi gadai saham.

Perlu dilihat lebih lanjut lagi, bahwa hak memesan saham terlebih dahulu ini memang suatu hak yang lahir karena adanya suatu perikatan, yaitu anggaran dasar perseroan. Akan tetapi selanjutnya Pasal 55 UU 40/2007 sendiri mengharuskan setiap pemindahan hak atas saham untuk mengikuti ketentuanketentuan yang diatur dalam anggaran dasar. Sedangkan kekuatan mengikat dari undangundang tidak tergantung pada kesepakatan orang, melainkan hanya dibatasi pada prinsip teritorial saja. Oleh karena itu, setiap orang di wilayah kedaulatan Indonesia harus mematuhi ketentuan Pasal 55 UU 40/2007, jadi dalam hal eksekusi gadai saham, para pihak juga memperhatikan ketentuan pasal ini.

Preemptive right hanya dapat dikecualikan dengan syarat-syarat limitative yang disebutkan di dalam Pasal 57 ayat (2) UU 40/2007 atau telah dilepaskan oleh pemilik preemptive right itu sendiri. 
Dalam sistem common law (khususnya Singapura dan Malaysia) terdapat ketentuan yang disebut sebagai Transfer Restriction. Perseroan wajib untuk mengeluarkan surat saham baru atas pemegang saham yang baru apabila pemindahan hak atas saham tersebut memenuhi tata cara peralihan hak yang diatur dalam peraturan perundangundangan dan tidak ada transfer restriction. Pada prinsipnya, setiap saham bebas untuk dialihkan tetapi harus mengikuti batasanbatasan yang ditetapkan dalam anggaran dasar. Salah satu batasan-batasannya adalah ketentuan mengenai keharusan untuk menawarkan saham terlebih dahulu kepada pemegang saham. Konsekuensinya bila hal ini tidak dilakukan oleh para pihak, maka perseroan tidak diwajibkan untuk mengelurkan surat saham baru atas nama pemegang saham yang baru tersebut. ${ }^{19}$

Pasal 97 Ayat (3), Ayat (4), dan Ayat (5) mengatur tentang tanggung jawab anggota Direksi atas kerugian perseroan yang timbul dari kelalaian menjalankan tugas pengurusan perseroan, yang dapat diklasifikasikan sebagai:

1) Anggota Direksi Bertanggung Jawab Penuh Secara Pribadi

Anggota Direksi bertanggung jawab penuh secara pribadi (persoonlijk aansprakelijk, personally liable) atas kerugian yang dialami perseroan apabila: ${ }^{20}$

a. Bersalah (schuld, guilt or wrongful act); dan

\footnotetext{
19 Walter Woon, Company Law, cetakan ke-2, Sweet \& Maxwell Asia, Malaysia, 2000, hal. 469-473.

20 M. Yahya Harahap, Hukum Perseroan Terbatas, Sinar Grafika, Jakarta, 2009, hal. 383.
}

b. Lalai (culpoos, negligence) menjalankan tugasnya melaksanakan pengurusan perseroan.

2) Anggota Direksi Bertanggung Jawab Secara Tanggung Renteng Atas Kerugian Perseroan.

Dalam hal anggota Direksi terdiri dari 2 (dua) orang atau lebih, maka Pasal 97 Ayat (4) menegakkan prinsip penerapan tanggung jawab secara tanggung renteng. Ketentuan Pasal 97 Ayat (4) UU 40/2007 tersebut adalah, "Dalam hal Direksi terdiri atas 2 (dua) anggota Direksi atau lebih, tanggung jawab sebagaimana yang dimaksud pada Ayat (3) berlaku secara tanggung renteng bagi setiap anggota Direksi”.

Berdasarkan bunyi dari Pasal 97 Ayat (4) ini, dengan demikian, apabila anggota Direksi lalai atau melanggar kewajibannya mengurus perseroan secara itikad baik dan penuh tanggung jawab sesuai dengan lingkup aspek-aspek itikad baik dan pertanggungjawaban pengurusan yang disebut di atas, maka setiap anggota Direksi sama-sama ikut memikul tanggung jawab secara tanggung renteng terhadap kerugian yang dialami perseroan.

Mengenai alasan pertimbangan penegakan prinsip tanggung jawab secara tanggung renteng ini, tidak dijelaskan dalam UU 40/2007. Menurut penulis pertimbangannya bertujuan agar semua anggota Direksi saling ikut menekuni secara terus-menerus pengurusan perseroan secara solidaritastanpamempersoalkanbidang tugas yang diberikan kepadanya, sehingga para Direksi itu secara keseluruhan harus bersatu 
dan penuh tanggung jawab bekerjasama mengurus kepentingan perseroan. Para Direksi itu harus menghindari terjadinya friksi yang diakibatkan oleh separation of power yang diembannya. Direksi harus sadar, setiap saat tanggung jawab secara tanggung renteng selalu menanti, meskipun kesalahan, kelalaian atau pelanggaran itu dilakukan oleh anggota Direksi yang lain, dan meskipun itu terjadi di luar bidang tugasnya serta hal itu terjadi di luar pengetahuannya atau walaupun seorang Direksi itu misalnya tidak ambil bagain sedikit pun atas peristiwa itu, tetap saja harus bertanggung jawab secara tanggung renteng atas kerugian yang dialami perseroan tersebut.

Penerapan tanggung jawab terhadap Direksi secara tanggung renteng di Indonesia baru dikenal setelah diberlakukannya UU 40/200. Sebelumnya, baik dalam Kitab Undang-Undang Hukum Dagang dan Undang-Undang Nomor 1 Tahun 1995 tentang Perseroan Terbatas, yang ditegakkan adalah prinsip tanggung jawab pribadi yang digantungkan kepada faktor siapa pelaku yang melakukan kesalahan, kelalaian atau pelanggaran, maka tanggung jawab hukumnya hanya dipikulkan kepada anggota Direksi yang melakukan kesalahan itu. Tidak dilibatkan anggota Direksi yang lain secara tanggung renteng.

Penerapan seperti itu, dikemukakan juga oleh Charlesworth dan Morse, ${ }^{21}$ dengan menyebutkan bahwa, "A Director is not liable for the acts of his Co-Director oh he has no knowledge and in which he

\footnotetext{
21 Charlesworth dan Morse., dalam M. Yahya Harahap., Ibid., hal. 385.
}

has taken no part, as his fellow Directors, Directors are not his servents or agents to impose liability on him". Dalam bentuk terjemahannya adalah, kalau tindakan kesalahan, kelalaian dan pelanggaran itu, dilakukan oleh seorang anggota Direksi tanpa sepengetahuan anggota Direksi yang lain atau dia tidak ikut ambil bagian atas perbuatan itu, anggota atau Co-Direksi yang lain tidak ikut bertanggung jawab terhadapnya. ${ }^{22}$

3) Pembebasan Anggota Direksi dari Tanggung Jawab Secara Tanggung Renteng

Seperti yang telah dijelaskan di atas, bahwa pad Pasal 97 Ayat (4) UU 40/2007 menganut prinsip penegakan tanggung jawab secara tanggung renteng terhadap setiap anggota Direksi atas kesalahan, dan kelalaian pengurusan yang dijalankan oleh anggota Direksi yang lain. Namun, penerapan prinsip itu dapat disingkirkan oleh anggota Direksi yang tidak ikut melakukan kesalahan dan kelalaian, apabila anggota Direksi yang bersangkutan dapat membuktikan hal-hal sebagai berikut: ${ }^{23}$

a. Kerugian perseroan tersebut bukan karena kelalaian atau kesalahan;

b. Telah melakukan dan menjalankan pengurusan perseroan dengan itikad baik dan kehati-hatian untuk ke-

22 Ibid.

23 Ibid., hal. 386. Menurut M. Yahya Harahap bahwa hal-hal yang disebutkan di atas, merupakan pengecualian dari tanggung jawab bersifat tanggung renteng terhadap anggota Direksi. Untuk itu, maka anggota Direksi harus bisa membuktikan hal-hal tersebut agar terlepas dari prinsip tanggung jawab yang bersifat tanggung renteng tersebut. Lihat juga Pasal 97 Ayat (5) UU 40/2007. 
pentingan perseroan sesuai dengan maksud dan tujua perseroan yang ditetapkan dalam Anggaran Dasar.

c. Tidak terdapat benturan kepentingan baik secara langsung maupun tidak langsung atas tindakan pengurusan yang mengakibatkan kerugian perseroan; dan;

d. Telah mengambil langkah sebagai tindakan untuk mencegah timbulnya atau berlanjutnya kerugian tersebut.

Hal ini sehubungan dengan bunyi Pasal 97 Ayat (5) huruf d UU 40/2007 yaitu, "Telah mengambil tindakan untuk mencegah timbul atau berlanjutnya kerugian tersebut". Yang dimaksud dengan "mengambil tindakan untuk mencegah timbul atau berlanjutnya kerugian", termasuk juga langkahlangkah untuk memperoleh informasi mengenai tindakan pengurusan yang dapat mengakibatkan kerugian antara lain melalui forum rapat Direksi.

Syarat-syarat pembebasan atau pelepasan dari tanggung jawab secara tanggung renteng yang dideskripsikan pada Pasal 97 Ayat (5) UU 40/2007 tersebut bersifat kumulatif, bukan alternatif, hal itu disimpulkan dari perumusannya. Antara syarat-syarat dalam Pasal 97 Ayat (5) huruf a, b, c, dan d, tidak terdapat kata "atau" yang mengandung makna yang berbeda. Walaupun ada kata atau akan tetapi maknanya sama saja menuju kepada satu jenis bukan dua jenis sehingga harus dipilih. Kemudian ditemukan pula kata "dan" antara huruf a, b, c, dan d. Bertitik tolak dari fakta perumusan yang disebut di atas, dapat disimpulkan bahwa syarat-syarat tersebut bersifat kumulatif. Kalau begitu, supaya seorang anggota Direksi dapat terhindar dan bebas dari tanggung jawab secara tanggung renteng atas kesalahan dan kelalaian anggota Direksi lain dalam pengurusan perseroan, anggota Direksi yang bersangkutan, harus dapat membuktikan hal-hal yang disebutkan pada Pasal 97 Ayat (5) huruf a, b, c, dan d tersebut. Satu hal saja tidak dapat dibuktikannya, kepadanya harus diterapkan penegakan prinsip tanggung jawab secara tanggung renteng sebagaiman yang telah ditentukan Pasal 97 Ayat (4) UU 40/2007. Akibat kerugian perseroan yang tidak dapat dibuktikan oleh Direksi seperti hal-hal yang telah disebutkan dalam Pasal 97 Ayat (5) itu, maka terhadap Direksi dapat diajukan gugatan perdata oleh para pemegang saham.

Dalam Pasal 97 Ayat (6) UU 40/2007 adalah, "Atas nama Perseroan, pemegang saham yang mewakili paling sedikit 1/10 (satu persepuluh) bagian dari jumlah seluruh saham dengan hak suara dapat mengajukan gugatan melalui pengadilan negeri terhadap anggota Direksi yang karena kesalahan atau kelalaiannya menimbulkan kerugian pada Perseroan".

Berdasarkan bunyi Pasal 97 Ayat (6) UU 40/2007 ini memberi hak kepada pemegang saham untuk mengajukan gugatan kepada Pengadilan Negeri terhadap hal-hal berikut ini:

a. Anggota Direksi yang melakukan kesalahan atau kelalaian dalam menjalankan pelaksanaan penguru- 
san perseroan;

b. Hak itu timbul, apabila kesalahan atau kelalaian itu menimbulkan kerugian pada perseroan; dan

c. Gugatan diajukan oleh pemegang saham atas nama perseroan, bukan atas nama perseroan sendiri.

Dalam hal ini UU 40/2007 sendiri memberi kedudukan (legal standing) atau legal persona standi in judicio menggugat anggota Direksi yang melakukan kesalahan atau kelalaian mewakili perseroan tanpa memerlukan Surat Kuasa Khusus dari perseroan atau RUPS maupun dari pemegang saham yang lain.

Dengan demikian, bilamana Direksi perseroan tidak melaksanakan ketentuan sebagaimana yang ditentukan dalam anggaran dasar perseoran (dalam hal ini saham yang dikeluarkan oleh perseroan tidak menawarkan saham terlebih dahulu kepada pemegang saham yang ada) dan hal tersebut telah membawa kerugian kepada para pemegang saham, maka para pemegang saham dapat mengajukan gugatan dengan dasar perbuatan melanggar hukum sebagaimana yang ditentukan dalam Pasal 1365 BW, sebagai berikut:

"Tiap perbuatan melanggar hukum, yang membawa kerugian kepada seorang lain, mewajibkan orang yang karena salahnya menerbitkan kerugian itu, mengganti kerugian itu".

Syarat-syarat tanggung gugat berdasarkan Pasal 1365 BW adalah sebagai berikut: ${ }^{24}$

24 J.H. Nieuwenhuis, Pokok-Pokok Hukum Perikatan, a. perbuatan yang menimbulkan kerugian itu bersifat melanggar hukum (perbuatan melanggar hukum);

b. kerugian itu timbul sebagai akibat perbuatan tersebut (hubungan kausal);

c. pelaku tersebut bersalah (kesalahan); dan

d. norma yang dilanggar mempunyai "strekking" untuk mengelakkan timbulnya kerugian (relativitas).

Perbuatan melanggar hukum, kesalahan, hubungan kausal dan relativitas, masing-masing merupakan syarat yang perlu (noodzakelijk), dan secara bersama merupakan syarat yang cukup (veldoende) untuk tanggung gugat berdasarkan Pasal 1365 BW.

Pasal 56 UU 40/2007 menentukan sebagai berikut:

(1) Pemindahan hak atas saham dilakukan dengan akta pemindahan hak.

(2) Akta pemindahan hak sebagaimana dimaksud pada ayat (1) atau salinannya disampaikan secara tertulis kepada Perseroan.

(3) Direksi wajib mencatat pemindahan hak atas saham, tanggal, dan hari pemindahan hak tersebut dalam daftar pemegang saham atau daftar khusus sebagaimana dimaksud dalam Pasal 50 ayat (1) dan ayat (2) dan memberitahukan perubahan

Tanpa Tahun Penerbitan, hal. 118. 
susunan pemegang saham kepada Menteri untuk dicatat dalam daftar Perseroan paling lambat 30 (tiga puluh) hari terhitung sejak tanggal pencatatan pemindahan hak.

(4) Dalam hal pemberitahuan sebagaimana dimaksud pada ayat (3) belum dilakukan, Menteri menolak permohonan persetujuan atau pemberitahuan yang dilaksanakan berdasarkan susunan dan nama pemegang saham yang belum diberitahukan tersebut.

(5) Ketentuan mengenai tata cara pemindahan hak atas saham yang diperdagangkan di pasar modal diatur dalam peraturan perundangundangan di bidang pasar modal.

Dari ketentuan tersebut, saham yang dikeluarkan tanpa terlebih dahulu tanpa ditawarkan terlebih dahulu kepada pemagang saham akan mengakibatkan saham tersebut akan menolak permohonan persetujuan pemindahan saham tersebut.

\section{Penutup}

Ruang lingkup prinsip kebebasan berkontrak meliputi kebebasan bagi para pihak untuk menentukan dengan siapa dia ingin atau tidak ingin membuat perjanjian dan kebebasan berkontrak meliputi kebebasan para pihak untuk menentukan sendiri isi perjanjian yang ingin mereka buat. Kebebasan bagi para pihak untuk menutup atau tidak menutup kontrak; Kebebasan untuk menentukan dengan siapa para pihak akan menutup kontrak; Kebebasan bagi para pihak untuk menentukan bentuk kontrak; Kebebasan bagi para pihak untuk menentukan isi kontrak; Kebebasan bagi para pihak untuk menentukan cara pembuatan kontrak.

Hak memesan saham terlebih dahulu (preemptive right) merupakan suatu hak yang lahir karena adanya suatu perikatan, yaitu anggaran dasar perseroan. Akan tetapi selanjutnya Pasal 55 UU 40/2007 juga mengharuskan setiap pemindahan hak atas saham untuk mengikuti ketentuan-ketentuan yang diatur dalam anggaran dasar.

Berdasarkan bunyi Pasal 97 Ayat (6) UU 40/2007 memberi hak kepada pemegang saham untuk mengajukan gugatan kepada Pengadilan Negeri terhadap hal-hal Anggota Direksi yang melakukan kesalahan atau kelalaian dalam menjalankan pelaksanaan pengurusan perseroan, Hak itu timbul, apabila kesalahan atau kelalaian itu menimbulkan kerugian pada perseroan; dan Gugatan diajukan oleh pemegang saham atas nama perseroan, bukan atas nama perseroan sendiri.

\section{Daftar Bacaan}

Asikin Kesuma Atmadja, Pembatasan Rentenir sebagai Perwujudan Pemerataan Keadilan, Varia Peradilan, Februari 1987.

Sentosa Sembiring, Hukum Perusahan tentang Perseroan Terbatas, Nuansa Aulia, Bandung, 2006.

Ridwan Khairandy, Perseroan sebagai Badan Hukum, Jurnal Hukum Bisnis, Volume 26, 2007. 
Mas Achmad Daniri, Good Corporate Governance Konsep dan Penerapannya dalam Konteks Indonesia, Gloria Printing, Jakarta, 2002.

M. Irsan Nasaruddin dan Indah Surya, Aspek Hukum Pasar Modal Indonesia, Preneda Media, Jakarta, 2004.

Tri Widiyono, Direksi Perseroan Terbatas, keberadaan, tugas, wewenang, dan tangung jawab, Ghalia, Jakarta, 2008 .

Robert J.P, Lebih Jauh tentang Kepailitan, Pusat Studi Hukum Bisnis Fakultas Hukum Pelita Harapan, Jakarta, 1998.
J. David Reitzel, et. Al., Contemporary Business law, Principles an Cases, cetakan ke-4, McGraw-Hill, United States, 1986.

Thomas J. Harron, Business Law, cetakan ke-1, Allyn and Bacon, Massachusets, 1981.

Walter Woon, Company Law, cetakan ke-2, Sweet \& Maxwell Asia, Malaysia, 2000 .

M. Yahya Harahap, Hukum Perseroan Terbatas, Sinar Grafika, Jakarta, 2009.

J. H. Nieuwenhuis, Pokok-Pokok Hukum Perikatan, Tanpa Tahun Penerbitan 